УДК 378.147:376.352 (477)

Шуневич Богдан Іванович, доктор педедагогічних наук, доцент, завідувач кафедри іноземних мов та технічного перекладу Львівського державного університету безпеки життєдіяльності, м. Львів

\title{
РОЛЬ ВИЩИХ ОСВІТНІХ ЗАКЛАДІВ В ОРГАНІЗАЦІЇ ДИСТАНЦЙНОГО НАВЧАННЯ В АМЕРИКАНСЬКИХ СЕРЕДНІХ ШКОЛАХ
}

\section{Анотація}

Актуальність матеріалу, викладеного у статті, обумовлена необхідністю впроваджувати нові інформаційні технології у вітчизняних загальноосвітніх школах. Мета статті - провести аналіз досвіду впровадження нової форми навчання середніми загальноосвітними школами США i, зокрема, за сприянням вищих навчальних закладів (ВН3). Цей досвід можна впровадити в українських школах. У статті коротко описано чотири види американських програм для отримання сертифікатів і дипломів про середню освіту в діалоговому режимі, а також проведено аналіз діяльності однієї із загальноосвітніх середніх шкіл при Університеті Міссурі, яка дистанційно проводить підготовку молоді до вступу у цей університет.

Ключові слова: дистанційне навчання, діалоговий режим навчання, середня загальноосвітня школа.

У науково-методичній літературі є багато публікацій стосовно різних аспектів впровадження дистанційного навчання (ДН) у вітчизняній і зарубіжній вищій школі $[1 ; 2]$. Цій тематиці присвячено також кілька українських і міжнародних конференцій $[3 ; 4]$.

Останнім часом опубліковано низку матеріалів про організацію ДН у середніх загальноосвітніх і спеціальних навчальних закладах України, виконуються проекти стосовно впровадження дистанційного навчання у цих освітніх закладах [5; 6].

Мета статті - провести аналіз впровадження нової форми навчання середніми загальноосвітними школами США i, зокрема, за сприянням вищих навчальних закладів. 
У США більшість дітей приходять у школу у віці 5 або 6 років і здобувають освіту у державних або приватних школах трьох рівнів: початковій (elementary school або primary school) — 5 років навчання, восьми (middle school) або дев'ятирічній (junior high school) - 3 або 4 роки навчання і середня (high school, senior high school) - 2 або 3 роки навчання.

Частина школярів з різних причин, наприклад діти з особливими потребами, не відвідують школу і навчаються вдома. У 2009 р. таких дітей було приблизно 1,5 мільйона, тобто 2,9\% всіх школярів. Для цієї категорії учнів у США існує мережа державних і приватних навчальних закладів для здобування повноцінної середньої освіти, наприклад: Американська академія (American Academy) [7], Віртуальна середня школа університету Індіана (Indiana University High School) [8], Середня школа університету Оклахоми (University of Oklahoma High School) [9], Освітня програма для обдарованої молоді Стенфордського університету (Stanford University Education Program for Gifted Youth) [10], Академія «Альфа-омега» (Alpha Omega Academy) [11]; Мічіганська віртуальна школа (Michigan Virtual School) [12], Середня школа університету Miccypi (University of Missouri High School) [13] та інші.

Американська академія пропонує понад 230 курсів у діалоговому режимі (online) для учнів середніх шкіл. Шестимісячний строк для завершення кожного курсу дає можливість для гнучкого планування графіку роботи учня.

Середня школа університету Індіана пропонує регіонально акредитовані програми для отримання сертифікатів про середню освіту за допомогою занять в діалогому режимі, а також кореспондентського навчання.

Середня школа університету Оклахоми має програму для отримання освіти за допомогою дистанційних Інтернет і кореспондентських курсів. Учні цієї школи мають доступ до більше 100 курсів, включно 3 вибірковими заняттями 3 журналістики, авіаційної техніки, латинської мови тощо.

Освітня програма для обдарованої молоді Стенфордського університету пропонує чіткий план роботи для учнів із винятковими здібностями. Середня школа 3 діалоговим режимом роботи забезпечує підготовку до екзаменів, доступ до деяких занять університетського рівня. 
Академія «Альфа-омега» $\epsilon$ школою дистанційного навчання, яка пропонує популярні навчальні програми релігійного спрямування за допомогою занять в діалоговому режимі, а також кореспондентських курсів.

У Мічіганській віртуальній школі зараз є 353 дистанційних курси. У каталозі школи $є$ шеститижневі курси трьох видів, які проводяться: 1) під керівництвом вчителя (Flex); з підтримкою вчителя (Pilot); учнями самостійно без участі вчителя (Student Direct).

За останні роки зросла кількість учнів, які здобувають знання за допомогою зручного, гнучкого дистанційного навчання, тому що більшість програм для отримання сертифікатів і дипломів про середню освіту, так само як для традиційного навчання, акредитовані регіональними акредитаційними комісіями. Отримані сертифікати і дипломи рівноцінні з тими, що отримані під час традиційного навчання школярів, i їх можна подавати для вступу в коледж, університет або за місцем працевлаштування. Учні традиційних шкіл також мають право час від часу користуватися послугами шкіл у діалоговому режимі, наприклад, користуватися деякими курсами для отримання сертифікатів з окремих дисциплін та ін.

Існує чотири види програм для отримання сертифікатів і дипломів про середню освіту в діалоговому режимі, а саме: в публічній середній школі (public online high school), яка підпорядковується місцевим або державним органами влади. Такі школи створені у багатьох штатах, навчання в них безплатне; у чартерній школі (online charter school), яка діє під керівництвом шкільної ради, але утримується державою. Ці школи пропонують освітні програми для отримання диплома про середню освіту студентам різних національних меншин, які живуть за межами своєї батьківщини. Держава покриває витрати учням на підручники, інші навчальні матеріали, а також програмне, апаратне забезпечення і навіть доступ до Інтернету; у приватній школі (online private school), яка не фінансується державою і не використовує обов'язкові державні навчальні плани і програми. Приватні школи, які працюють в діалоговому режимі, часто є у власності корпорацій, діють на неприбутковій основі і дорого обходяться корпорації або батьким цих учнів, тому програми навчання в них гнучкіші, ніж у державних школах; у школі, яка спонсорується і керується коледжем або університетом (college-sponsored online high school, university-sponsored online high school). Усе більше традиційних університетів організовують середні школи, які 
пропонують навчальні програми у діалоговому режимі. Ці школи відрізняються навчальними планами і вартістю навчання в них, але всі вони акредитовані й користуються високим попитом у населення. До навчального процесу залучається професорсько-викладацький штат коледжу чи університету. Учні мають доступ до дистанційних курсів вищого навчального закладу. Такі школи також розраховані на роботу з обдарованими учнями, майбутніми студентами цього ВНЗ.

Дорослі люди також можуть навчатися у середній школі, у тому числі в кількох школах з прискореним графіком здобування середньої освіти, щоб у майбутньому мати можливість поступити у вищі навчальні заклади. Для покриття фінансових витрат у приватних школах, таким учням пропонуються грошові позички на навчання.

Учні, які навчаються в діалоговому режимі, можуть поєднувати навчання 3 роботою у вільний від навчання час, а також навчатися у потрібному для них темпі.

Опишемо детальніше організацію навчання в середній школі Університету Micсурі [13], у яку кожного року поступають понад 7000 учнів. Ця школа зручна тим, що в ній можна розпочати навчання у будь-який час навчального року, вчитися у найбільш прийнятному для себе темпі. Курс навчання розрахований максимум на дев’ять місяців у діалоговому режимі для кожного предмету середньої школи. Учні беруть участь у позашкільній роботі згідно з навчальною програмою, вивчають додаткові предмети, яких немає в традиційних середніх школах. Вартість цих курсів удвічі менша, ніж в інших середніх школах. Ще однією особливістю цієї школи є використання програм паралельного вивчення учнями деяких дисциплін шкільного та університетського рівнів, а також організація роботи з обдарованою молоддю з метою підготовки їх до навчання у вищих освітніх закладах.

Цей навчальний заклад пропонує понад 200 курсів із різних предметів у діалоговому режимі для середньої школи. Серед них 3 курси 3 дисциплін, які стосуються сільського господарства, наприклад, «Вступ до предмету про сільське господарство», 20 - з бізнесу і комп’ютерних наук, наприклад, «Економіка», «Вступ до предмету про комп’ютерні та інформаційні технології», 1 - 3 шоферської справи, 7 - 3 наук про сім’ю і споживчі товари, наприклад, «Одяг і текстильні вироби», 9 3 різних питань щодо мистецтва, наприклад, «Історія мистецтва», 27 - 3 іноземних мов (французської, німецької, японської, латинської, іспанської), 2 - $з$ наук про 
здоров’я, наприклад, «Здоров’я», $42-3$ теорії і практики рідної мови та літератури, наприклад, «Критичне мислення», «Афро-американська література», 29 - 3 математики, наприклад, «Алгебра», «Статистика», $8-3$ наук про особистий розвиток, наприклад, «Планування кар'єри», 17 - з астрономії, біології, хімії, фізики, геології, 32 - із соціальних наук, наприклад, «Історія Америки», «Психологія», «Соціологія».

Навчання з усіх дисциплін завершується екзаменами. Уся інформація про досягнення учнів зберігається у Центрі дистанційного і кореспондентського навчання.

Крім цього в школі пропонують курси для обдарованих учнів та 3 предметів, які вивчаються в коледжах і університетах.

Навчання обдарованих дітей проводиться в денній і дистанційній формах. Наприклад, учням цієї середньої школи пропонують 3 дисципліни стосовно мистецтва, 14 - 3 іноземних мов (німецької, японської, латинської), 7 - 3 британської, американської та афро-американської художньої літератури, 4 - 3 математики, 4 - з астрономії і фізики, 10 - із соціальних наук.

Популярними у цих школах $є$ паралельне навчання учнів за шкільною та університетськими програмами, щоб економити час і гроші за навчання. У середній школі Університету Міссурі центр дистанційного і кореспондентського навчання організував програми, що дають можливість учням вивчати курси університетського рівня, що на 50\% здешевлює вартість оплати за навчання у вищому навчальному закладі.

Викладачі Університету Міссурі розробили навчальні курси університетського рівня для паралельного вивчення їх учнями середньої школи з літератури, іноземних $\mathrm{i}$ рідної мов, математики, природничих i соціальних наук, а саме: 2 курси 3 антропології, 1 - 3 біології, 13 - 3 англійської мови та літератури, 3 - 3 кінематографії, 1 - 3 фінансів, 3 - 3 географії, 1 - 3 геологічних наук, $9-3$ іноземних мов, 5 - з історії, 2 - 3 математики, 1 - з туризму, $3-3$ філософії, $1-3$ фізики і астрономії, 1 - 3 політичних наук, 2 - 3 психології, 2 - із соціології, 1 - зі статистики, 1 - $з$ технічної комунікації (Technical Communication) i 1 - 3 гендерних студій.

За університетською програмою мають право навчатися учні середньої школи, які мають в середньому бали не нижче B+ за системою оцінювання A, B, C, D, F; 
входять до списку кращих за рейтингом (25\%) учнів класу, у якому вони навчаються; мають рекомендацію від директора школи про те, що вони академічно готові вивчати курси університетського рівня. Учням дозволяють паралельно вивчати чотири курси 3 різних дисциплін. Навчання здійснюється посеместрово або у зручному режимі для учнів різного віку.

Середня школа Університету Міссурі акредитована Комісією для міжнародної і трансрегіональної акредитації (Commission on International and Transregional Accreditation), а також Комісією Північної центральної асоціації 3 акредитації i вдосконалення роботи школи (North Central Association Commission on Accreditation and School Improvement).

Із проведеного дослідження можна зробити такі висновки:

1. Середні школи США успішно використовують чотири види програм для отримання сертифікатів і дипломів про середню освіту в діалоговому режимі: в публічній, чартерній, приватній школах, а також школах, які спонсоруються i керуються коледжем або університетом.

2. Провідну роль у налагодженні роботи у школах, які спонсоруються i керуються коледжем або університетом, відіграють американські ВНЗ, які вже мають великий досвід у впровадженні дистанційного, у тому числі діалогового режиму, під час викладання/вивчення різних дисциплін за допомогою звичайної пошти, а останнім часом через Інтернет та іншими засобами зв'язку.

3. На нашу думку, основними завданнями діяльності таких шкіл є підготовка молоді до вступу у ВНЗ. 3 цією метою викладачі вищих навчальних закладів розробляють дистанційні курси (ДК) з різних дисциплін для паралельного вивчення їх у середній школі, які потім зараховуються цим учням, майбутнім студентам коледжів та університетів, у яких створені такі віртуальні середні школи. Отже, відбувається економія часу і коштів під час навчання у вищому навчальному закладі.

4. Деякі вищі навчальні заклади та організації в Україні також допомагають загальноосвітнім школам у впровадженні дистанційного навчання. Наприклад, Український інститут інформаційних технологій в освіті [14] і Національний технічний університет «Харківський політехнічний інститут» [15] пропонують школам 17 дистанційних курсів із різних дисциплін. Останнім часом ці дві установи використовують для укладання ДК віртуальне навчальне середовище «Moodle». Якщо 
навчальні заклади об'єднають свої зусилля, то найближчим часом, використовуючи їхній великий досвід у цьому напрямі, середні школи східної і центральної України зможуть отримати велику кількість ДК з різних дисциплін.

5. Щоб прискорити впровадження дистанційного навчання в загальноосвітніх школах у західних областях України, 30 жовтня 2010 р. в рамках IV Міжнародної конференції «Лінгвістичні проблеми та інноваційні підходи до викладання чужоземних мов у вищих навчальних закладах» був проведений семінар для вчителів шкіл, ліцеїв, технікумів, коледжів, училищ, під час якого було прочитано лекції стосовно стану впровадження дистанційного навчання в таких закладах в Україні та США [16], а також заплановано наступні зустрічі з цієї тематики.

\section{Список використаних джерел}

1. Шуневич Б. Тенденції розвитку дистанційного навчання у зарубіжній вищій школі // Інформаційні технології і засоби навчання: Електронне наукове фахове видання. - Київ, 2008. - Вип. 3(7). - Режим доступу: http://www.ime.eduua.net/em.html. - Заголовок з екрана.

2. Коваль М. Шляхи популяризації комбінованого і дистанційного навчання у Львівському державному університеті безпеки життєдіяльності / М. Коваль, Б. Шуневич // Педагогіка і психологія професійної освіти. — 2007. — № 1. — С. 207210.

3. «Інтернет — освіта — наука — 2008», IOH-2008: Збірник матеріалів шостої міжнародної конференції, м. Вінниця, 7-11 жовт. 2008 р. [Текст] = Internet Education - Science. IES-2008 / Вінницьк. нац. техн. ун-т. - Вінниця: УНІВЕРСУМВінниця, 2008. - Текст кн. укр., англ., рос. мовами. Т. 1(9). - Вінниця, 2008. - 310 c.

4. Комп'ютерна підтримка навчальних дисциплін у середній і вищій школі: Матеріали II Всеукр. наук.-практ. конф., м. Луганськ, 8-9 груд. 2005 р. - Луганськ: Альма-матер, 2005. - 157 с. 
5. Моклюк М. О. Методика використання елементів дистанційних технологій у процесі навчання фізики в загальноосвітніх навчальних закладах: дис. ... канд. пед. наук: 13.00.02 / М. О. Моклюк; керівник роботи В. Ф. Заболотний; НПУ імені М. Драгоманова. — Київ, 2009. — 197 с.

6. Богачков Ю. М. Концепція проекту «Дистанційне навчання школярів» / Ю. М. Богачков, В. Ю. Биков, В. О. Красношапка, В. М. Кухаренко, Ю. Я. Пасіхов // Інформаційні технології і засоби навчання. — 2009. — №5 (13). - Режим доступу до журналу: http://www.ime.edu-ua.net/em.html. - Заголовок з екрана.

7. American Academy. - Режим доступу до Веб-сторінки: http://www.theamericanacademy.com/SaaS. - Заголовок з екрана.

8. Indiana University High School. - Режим доступу до Веб-сторінки: http://iuhighschool.iu.edu. - Заголовок з екрана.

9. University of Oklahoma High School. - Режим доступу до Веб-сторінки: http://ouhigh.ou.edu/. - Заголовок з екрана.

10. Stanford University Education Program for Gifted Youth. — Режим доступу до Веб-сторінки: http://distancelearn.about.com/od/highschoolprofiles/p/EPGYscho. Заголовок з екрана.

11. Alpha Omega Academy. - Режим доступу до Веб-сторінки: http://www.aoacademy.com/. - Заголовок з екрана.

12. Michigan Virtual School. - Режим доступу до Веб-сторінки: http://www.mivhs.org/. - Заголовок з екрана.

13. University of Missouri High School. - Режим доступу до Веб-сторінки: http://cdis.missouri.edu/high-school.aspx. — Заголовок з екрана.

14. Український інститут інформаційних технологій в освіті. - Режим доступу до Веб-сторінки: http://udec.ntu-kpi.kiev.ua. — Заголовок з екрана.

15. Національний технічний університет «Харківський політехнічний інститут». — Режим доступу до Веб-сторінки: http://dl.kpi.kharkov.ua. — Заголовок 3 екрана.

16. Лінгвістичні проблеми та інноваційні підходи до викладання чужоземних мов у вищих навчальних закладах: Програма IV Міжнародної науково-практичної конференції, м. Львів, 28-30 жовтня 2010 р. — Львів: ЛДУ БЖД. — 32 с. 


\section{РОЛЬ ВЫСШИХ ОБРАЗОВАТЕЛЬНЫХ УЧРЕЖДЕНИЙ В ОРГАНИЗАЦИИ ДИСТАНЦИОННОГО ОБУЧЕНИЯ В АМЕРИКАНСКИХ СРЕДНИХ ШКОЛАХ}

Шуневич Б. И.

\section{Аннотация}

Актуальность изложенного в статье материала обусловлена необходимостью внедрять новые информационные технологии в отечественных общеобразовательных школах. Цель статьи - провести анализ опыта внедрения новой формы обучения в средних общеобразовательных школах США и, в частности, при содействии высших учебных заведений. Этот опыт можно внедрить в украинских школах. В статье кратко описаны четыре вида американских программ для получения сертификатов и дипломов о среднем образовании в диалоговом режиме, а также проведен анализ деятельности одной из общеобразовательных средних школ при Университете Миссури, которая дистанционно проводит подготовку молодежи к вступлению в этот университет.

Ключевые слова: дистанционное обучение, диалоговый режим обучения, средняя общеобразовательная школа.

\section{ROLE OF HIGHER EDUCATIONAL ESTABLISHMENTS IN DISTANCE LEARNING IMPLEMENTATION AT AMERICAN HIGH SCHOOLS} Shunevych B.

\section{Resume}

Relevance of the material contained in the article is tasked by the necessity to implement new information technologies at national high schools with the assistance of higher school. The purpose of the article is to analyse the foreign experience of implementing new forms of learning by American high schools and, in particular, with the assistance of higher education institutions. This experience can be implemented at the Ukrainian schools. The article briefly describes four kinds of American programs for getting certificates and diplomas of secondary education in an interactive mode as well as it is provided the analysis of the University of Missouri High School activity, that successfully realizes training of young people in an interactive mode for entering this university.

Keywords: distance learning, interactive mode of learning, secondary school. 